\title{
STUDYING LISTENING DIFFICULTIES OF MEDICAL DOCTOR STUDENTS AT THAI NGUYEN UNIVERSITY OF MEDICINE AND PHARMACY
}

\author{
Nguyen Quynh Trang ${ }^{1}$, Duong Cong Dat ${ }^{2 *}$, Dang Phuong Mai ${ }^{3}$ \\ ${ }^{I} T N U$ - University of Medicine and Pharmacy, ${ }^{2} T N U$ - University of Education, \\ ${ }^{3} \mathrm{TNU}-$ University of Information and Communication Technology
}

\begin{abstract}
The study was conducted to find out the listening difficulties of the first year Medical doctor students who were studying English 1 and English 2 at University of Medicine and Pharmacy Thai Nguyen University and then proposed some possible solutions to improve their listening skill. The study employed quantitative method to collect data via questionnaire and interview. The results of the study revealed that the majority of listening difficulties pertains to two main factors, namely the speakers, and the listeners. Specifically, students' listening difficulties include intonation, word stress, speed of speech, ending sounds, elision and linking sounds, insufficient vocabulary in medical fields, lacking basic knowledge and medical knowledge. Based on the findings, the study proposes some effective methodological practices to improve students' listening skills.

Keywords: communicative English; listening skill; listening comprehension; difficulties in listening skill; difficulties in listening comprehension
\end{abstract}

Received: 21/8/2020; Revised: 19/10/2020; Published: 20/10/2020

\section{KHẢO SÁT NHŨ̃NG KHÓ KHĂN TRONG VIÊC HỌC KỸ NĂNG NGHE CỦA SINH VIÊN BÁC SĨ Y KHOA TAI TRƯỜNG ĐAI HỌC Y DƯỢC - ĐẠI HỌC THÁI NGUYÊN}

\author{
Nguyễn Quỳnh Trang ${ }^{1}$, Dương Công Đạt ${ }^{2^{*}}$, Đặng Phương Mai ${ }^{3}$ \\ ${ }^{I}$ Truoòng Đại học Y Duợc - ĐH Thái Nguyên \\ ${ }^{2}$ Trưòng Đai học Su phàm - ĐH Thái Nguyên \\ ${ }^{3}$ Truò̀ng Đại học Công nghệ thông tin và Truyền thông - ĐH Thái Nguyên
}

\section{TÓM TẮT}

Nghiên cứu này được tiến hành nhằm tìm hiểu những khó khăn của nghe hiểu mà sinh viên bác sĩ Y khoa năm thứ nhất trường Đại học Y Dược - Đại học Thái Nguyên gặp phải khi học tiếng Anh1 và tiếng Anh 2 , từ đó đề xuất một số giải pháp để cải thiện kỹ năng nghe hiểu cho sinh viên. Nghiên cứu sử dụng phương pháp nghiên cứu định lượng để thu thập dữ liệu qua bảng câu hỏi điều tra và phỏng vấn. Kết quả từ khảo sát chỉ ra rằng, những khó khăn chủ yếu mà sinh viên gặp phải khi học kỹ năng nghe liên quan đến hai yếu tố chính: từ người nói, và từ người nghe. Cụ thể, những khó khăn của sinh viên khi nghe gồm có ngữ điệu của câu, trọng âm của từ, tốc độ, âm cuối, các hình thức nuốt âm và nối âm, thiếu từ vựng chuyên ngành, thiếu kiến thức cơ bản và chuyên ngành $\mathrm{y}$. Nghiên cứu đã đề xuất các giải pháp thích hợp để việc học kỹ năng nghe của sinh viên tích cực và hiệu quả hơn trong lớp học.

Từ khóa: Tiếng Anh giao tiếp; kỹ năng nghe; kỹ năng nghe hiểu; nhũng khó khăn trọng việc học kỹ năng nghe; nhũng khó khăn khi học nghe hiểu

Ngày nhận bài: 21/8/2020; Ngày hoàn thiện: 19/10/2020; Ngày đăng: 20/10/2020

* Corresponding author. Email: datdc@tnue.edu.vn

DOI: https://doi.org/10.34238/tnu-jst.3513 


\section{Introduction}

Training learners' skills of communicating and using foreign languages are considered a fundamental goal of teaching and learning English at the tertiary level in Vietnam. Since the school year 2017-2018, Thai Nguyen University of Medicine and Pharmacy (TUMP) has implemented the integration of foreign language modules with English for specific purposes (ESP) to help students apply their language abilities to study specialized subjects which were taught in English. Among the four basic major-skills of learning English, listening comprehension is the decisive skill to acquire language and to process information. Flavia [1] affirmed that listening is no longer a passive skill but becomes an active skill, in which learners play an active role in listening and processing information, understanding the content and finally giving feedback to that information.

According to Hamouda [2], language learners often have trouble with listening comprehension because teachers often focus on teaching the knowledge of grammar, vocabulary, and reading ability at high school. Although innovative textbooks are designed with listening parts, listening skills are not taught and practiced as often as other skills. Furthermore, through observations at many schools in rural or mountainous areas, the teaching of listening skills is even ignored due to poor facilities, poor quality of loudspeakers, and no listening parts in the examinations. According to the Student Affairs Department, the majority of TUMP's students come from Region II, Region III in rural areas and the northern mountainous provinces of Vietnam. There are only a few students coming from big cities. Consequently, the majority of TUMP's students have difficulty in learning listening skills, especially listening to specialized fields when studying English 1 and 2.
As TUMP's teacher of English for 10 years, the researcher found that studying the main difficulties that students face when learning listening skills is essential. The researcher expected that the solutions of the research not only help teachers choose appropriate teaching methods but also help learners improve their listening skills.

\section{Subjects and methods of the study}

To choose the samples of the study, the researcher used Slovin's formula $\mathrm{n}=\mathrm{N} /(1+$ $\mathrm{Ne}^{2}$ ) (with e $=5 \%$ ) and got the sample size of 219 students of the total of 475 students. They were the freshmen and were studying English 1 and 2 at TUMP in the first and second semester of the school year 2019-2020.

In this study, the researcher used quantitative approaches in order to provide a more complete understanding of the research problem. The primary tool for collecting data used in this study was the questionnaire, which was divided into 2 main groups of difficulties: from the speaker and from the listener perspectives. The researcher also used 4 open-ended questions to interview 10 students, 5 students with good listening test results and 5 students with low listening test results to provide more corroborative evidence to the results of the study.

The researcher used Statistical Package for the Social Science (SPSS ver 20.0) to analyze and interpret the data gathered from questionnaires. With the help of the software, the researcher determined to obtain accurate results of frequency counts, percentage, mean rating and weighted mean of difficulty in listening. The data from the interviews was inputted into Microsoft Excel software and then was calculated.

\section{Findings and discussion}

\subsection{Difficulties from speakers}

The listening difficulties from the speakers are illustrated in Table 1. It shows that the highest percentage of the difficulty which students encounter is the last sounds (s, es, ed, 
$k, t, f . .$.$) with the mean value of 3.69. This$ data shows that the ending sounds are one of the biggest challenges for students in acquiring information. This may be because students' pronunciation is not correct or the final sounds in English are not paid much attention when pronouncing. Gilakjani [3] said that if a word is pronounced differently from the way it was pronounced during learning, the listener cannot realize that it is the same word. They even forget the existence of it. The second difficulty is the fast speaking speed and intonation, and the speaker's stress with a mean of 3.68. Likewise, the simplified forms (swallowing and linking) and strange pronunciation also contribute to hindering students' listening comprehension. Conversely, noise and other interrupting sounds are the least difficult. It can be said that recordings from the speaker handle sound well.

Regarding to the level of difficulty from the speaker, Table 2 shows that students often have difficulty in hearing the last sound accounting for $65.2 \%$, followed by the strange pronunciation with the high level of difficulty of $64.3 \%$. Words stress and intonation are also difficulties that most students face with as high as $63 \%$. In addition, the fast speaking speed in the recordings also made it difficult for students to listen with high level of $61.2 \%$. This result is the same in the research by [4] "Fast speed is the biggest obstacle for students because the majority of students do not follow the sequence of words and cannot understand the content of listening comprehension".

Table 1. Difficulties from speakers

\begin{tabular}{lccc}
\hline & Samples & Mean & Std. Deviation \\
\hline 1. Fast speed & 219 & 3.68 & .822 \\
2. Strange pronunciation & 219 & 3.51 & .925 \\
3. Number of speakers (more than 2) & 219 & 2.49 & 1.042 \\
4. Ending sound (es, ce, se, ed, k, t...) & 219 & 3.69 & .884 \\
5. Simplified forms (swallowing and linking) & 219 & 3.65 & .924 \\
6. Word stress, intonation of the sentence & 219 & 3.68 & .897 \\
7. Signal words (however, although, but...) & 219 & 2.91 & .924 \\
8. Colloquial word (wanna, gotta, gonna...) & 219 & 2.74 & 1.121 \\
9. Noise and other interrupted sound & 219 & 2.81 & 1.125 \\
\multicolumn{1}{c}{ Overall mean } & & $\mathbf{3 . 2 4}$ & \\
\hline Legend: 1 - 1.79: never/ rarely & 1.8-2.59: sometimes & $2.6-3.39:$ often
\end{tabular}

Table 2. Level of difficulty from the speaker

\begin{tabular}{lccc}
\hline \multirow{2}{*}{\multicolumn{1}{c}{ The difficulties }} & \multicolumn{3}{c}{ Level (\%) } \\
\cline { 2 - 4 } & Low & Medium & High \\
\hline 1. Fast speed & 9.6 & 29.2 & 61.2 \\
2. Strange pronunciation & 13.3 & 32.4 & 64.3 \\
3. Ending sound (es, ce, se, ed, k, t ...) & 9.2 & 25.6 & 65.2 \\
4. Simplified forms (swallowing and linking) & 10 & 26 & 64 \\
5. Word stress, intonation of the sentence & 13.3 & 23.7 & 63 \\
\hline
\end{tabular}

Legend: Low $=$ never + sometimes

High = usually + always

Medium $=$ often

http://jst.tnu.edu.vn; Email: jst@tnu.edu.vn 


\subsection{Difficulties from listeners}

From Table 3, it can be seen that the lack of specialized vocabulary is the most difficult factor for students to study English programs integrated with specialized modules. It accounts for the highest mean value of 3.80 . This indicates that students do not have a sufficient amount of specialized English knowledge to be able to listen and understand the context. The second difficulty with an average mean value of 3.79 is that students do not have an effective listening method. Most students have a habit of trying to hear each word. They do not have enough vocabulary to judge the context and guess the context. The lack of basic and specialized knowledge ranks third among the listener's difficulty with an average mean value of 3.75 . The causes of the problems may be because students do not focus on English at high school. Most of them focus on the subjects which are for university entrance. The next difficulty is the students' poor pronunciation, inaccuracies and the limited ability to judge the content with the mean value of 3.68. On the contrary, poor psychology, health as well as the ability to focus are not challenging for students. The table points out that students have a stable mentality, good health and concentration ability when learning a foreign language with average mean values for each category of 2.83 and 2.85 respectively.

It can be clearly seen from Table 4 that students have the most difficulty in listening because the lack of specialized vocabulary accounts for $73 \%$ in high level. The next difficulty level is the lack of basic and specialized knowledge with a high level of $67.6 \%$. An ineffective listening method which accounts for a high level of $63 \%$ shows that students have not been advised to choose an effective listening method when learning English 1 and 2 at TUMP.

Table 3. Difficulties from listener

\begin{tabular}{lc|c|c}
\hline & Sample & Mean & Std. Deviation \\
\hline 10. Lack of specialized vocabulary & 219 & 3.80 & .969 \\
11. Lack of basic and specialized knowledge & 219 & 3.75 & .980 \\
12. Psychological and health problems (sad, worried, tired ...) & 219 & 2.83 & 1.155 \\
13. Poor / inaccurate pronunciation & 219 & 3.68 & 1.049 \\
14. Poor concentration & 219 & 2.85 & 1.018 \\
15. The ability to judge the content is limited & 219 & 3.54 & .992 \\
16. The listening method is not effective (trying to hear each word ...) & 219 & 3.79 & .918 \\
\multicolumn{1}{c}{ Overall mean } & & $\mathbf{3 . 4 6}$ & \\
\hline Legend: 1-1.79: never/ rarely & 2.6-3.39: often & & $4.2-5.0:$ always \\
1.8-2.59: sometimes & $3.4-4.19:$ usually & &
\end{tabular}

Table 4. Level of difficulty from the listener

\begin{tabular}{lccc}
\hline \multirow{2}{*}{ The difficulties } & \multicolumn{3}{c}{ Level (\%) } \\
\cline { 2 - 4 } & Low & Medium & High \\
\hline 6. The lack of specialized vocabulary & 11 & 16 & 73 \\
7. Lack of basic and specialized knowledge & 10 & 22.4 & 67.6 \\
8. Inaccurate pronunciation & 13.7 & 26.9 & 59.4 \\
9. The ability to judge the content is limited & 17.3 & 27.4 & 55.3 \\
10. The listening method is not effective (trying to hear each word....) & 7.3 & 29.7 & 63 \\
\hline
\end{tabular}




\subsection{Interview result}

When answering about the amount of time students spend listening at home, $100 \%$ of students with low listening test results said that they did not spend time listening at home. This result is similar to the conclusion that the author [5] has pointed out "Most students do not spend time practicing listening every day". Meanwhile, $100 \%$ of students with good listening results said that they listened to English whenever they have time. They often listened to English songs or English news.

When answering the question "How do you think about listening lessons on class?" 100\% of both groups thought that listening was difficult. In addition, when the author suggested about well-prepared pre-listening, $80 \%$ of students with good listening results hoped they could follow the listening lessons well. Meanwhile, $100 \%$ of students with low listening test results had a neutral answer - "I don't know."

\section{Proposed major solutions and conclusions}

\subsection{Some solutions to improve English listening comprehension skills for students}

\subsubsection{For lecturers}

Lecturers should improve student pronunciation by making them to listen to different tones or practice listening and speaking with native speakers. They should ask students to learn by heart specialized vocabulary, and build their own specialized knowledge. Teachers should edit and improve the listening materials in order to motivate students to listen well. They also should guide students effective listening strategies...

Although the curriculum has designed listening and understanding activities, lecturers still need to design more prelistening activities in an easy suitable and attractive way for both fair and weak students. Getting students familiar with the specialized vocabulary that will appear in the listening lesson will also help students to access and understand the listening lessons more easily. Some techniques can be applied such as: using medical situations for role-playing, videos about clinical situations so that students can actively discuss related topics before listening, using games or visual aids to engage students in the topic of the listening lesson while giving students listening tasks ...

Teachers need to make the lesson more vivid by combining different methods because listening requires intensive concentration and it is difficult to maintain student interest. Teachers can choose listening songs with funny illustrations, attractive content or they can listen to the songs and ask students to fill in the blanks. The teacher can show or listen to a clinical situation, and students record as much dialogue as possible.

\subsubsection{For students}

First of all, students need to increase their self-practice time at home by practicing listening to good, easy-to-use, and appropriate listening resources (books, CDs, websites). In addition, students need to realize that persistence and regular practice are the keys to success for this subject.

Furthermore, they also need to improve their understanding of a specialized field by reading and viewing specialized knowledge written in English on the World Health Organization website. Besides, students need to be bold, proactively communicate with foreign students in Thai Nguyen University or teachers, foreigners speaking English in the University. Active communication with foreigners is also one of the important factors that help students improve their listening comprehension ability.

\subsubsection{For university}

In order to help students effectively self-study English in general and listening comprehension skills in particular, the school needs to equip classrooms, reading rooms, 
libraries, with materials and convenient technical equipment. For example, classrooms must be equipped with sound systems, audiovisual systems, projectors, and internet networks with good transmission lines to avoid blurry images and unclear sound.

\subsection{Conclusion}

Through research and investigation of the difficulties in learning listening skills of first year students of Medical Doctor, we can see the role and importance of listening skills when learning foreign languages in general and listening to English in the field specialized in particular. However, listening is considered the most difficult of the language skills (Listening, speaking, reading and writing). Therefore, the teacher is the first factor determining the student's development, so teachers have to improve their teaching style, provide qualified materials and always innovate the content so that it is vivid, accessible and engaging with students who love the subject. As for learners, it is necessary to identify the importance of listening comprehension skills in communication and future careers, thereby enhancing self listening practice, supplementing knowledge of English in specialized fields.

\section{REFERENCES}

[1]. M. Flavia, and L. Enachi-Vasluianu, "The Importance Of Elements Of Active Listening In Didactic Communication: A Student'S Perspective," CBU International Conference Proceedings, ISE Research Institute, vol. 4, no. 0, pp. 332-335, 2016.

[2]. A. Hamouda, "An Investigation of Listening Comprehension Problems Encountered by Saudi Students in the EL Listening Classroom," International Journal of Academic Research in Progressive Education and Development, vol. 2, no. 2, pp. 113-155, April 2013. [Online]. Available: https://pdfs.semanticscholar.org/b811/984d6e30 068a62a970b1f75b2e701e0b159e.pdf?_ga=2.26 5239559.969429323.1597925080-669699048. 1587711147. [Accessed: May 12, 2020]

[3]. A. P. Gilakjani, and M. R. Ahmadi, "A Study of Factors Affecting EFL Learners' English Listening Comprehension and the Strategies for Improvement," Journal of Language Teaching and Research, vol. 2, no. 5, pp. 977-988, 2011.

[4]. J. Flowerdew, and L. Miller, "Student Perceptions, Problems and Strategies in Second Language Lecture Comprehension," RELC Journal, vol. 23, no. 2, pp. 60-80, December 1992. [Online]. Available: https://doi.org/10.1177/00336882920230020. [Accessed: May 12, 2020].

[5]. N. T. T. Thao, "The Difficulties in Learning Listening of first-year students at Hanoi National University of Education," ULIS, VNU, 2013. [Online]. Available: http://repository.ulis.vnu.edu.vn/bitstream/UL IS_123456789/2037/1/Nguyen\%20Thi\%20Th u\%20Thao_qh09.e5_GHP_edited\%20\%28pdf .io\%29.pdf. [Accessed: May 12, 2020]. 